Tiago José Santos de Matos Ferraz ${ }^{1}$

Carla Maria Magno Bartosch ${ }^{2}$

Carla Maria Almeida Ramalho ${ }^{2}$

Filipa Abreu Gomes de Carvalho 3

Berta Cécíla Campos lima de Carvalho ${ }^{3}$

Otíla Gonçalves Bento Cavalero Brandão²

Nuno Aires MOta MENDOnÇa MONTENEGRO²

Relato de Caso

Keywords

Hydatidiform mole

Sperm injections, intracytoplasmic

Pregnancy, twin

Case reports

Palavras-chave

Mola hidatiforme Injeções de esperma intracitoplásmicas

Gravidez de gêmeos

Relatos de casos

\title{
Complete mole in a dichorionic twin pregnancy after intracytoplasmic sperm injection
}

\author{
Mola bidatiforme completa em gravidez bicoriônica após injecção \\ intracitoplasmática de espermatozoides
}

Abstract

A dichorionic twin pregnancy with complete hydatidiform mole and coexistent fetus is a rare and challenging situation, whose pathogenesis has not been yet fully understood. We present a case of a 39-year-old woman who underwent intracytoplasmic sperm injection with two embryos transfer. The 12-week gestation ultrasound examination revealed normal fetus and placenta with features of hydatidiform mole, leading to pregnancy termination. Autopsy and histological examinations diagnosed a complete mole coexisting with a normal fetus, and the genetic analysis showed a diploid fetus with biparental genome and molar tissue with paternal diploidy. This case highlighted that complete molar pregnancies may still occur even though pregnancy is achieved after intracytoplasmic sperm injection. A review of the literature was performed by collecting data from the few similar reported cases and by commenting on the pathogenesis of this rare condition.

\section{Resumo}

Uma gravidez bicoriônica com mola hidatiforme completa e feto normal é uma situação rara e desafiadora, cuja patogênese não foi ainda totalmente compreendida. Apresenta-se o caso de uma mulher de 39 anos submetida à injeção intracitoplasmática de espermatozoides com transferência de dois embriões. Na ecografia pré-natal realizada na $12^{a}$ semana de gestação, foi identificado um embrião morfologicamente normal e uma placenta com características molares. Esta situação resultou na terminação eletiva da gravidez. A autópsia e o estudo histológico permitiram o diagnóstico definitivo de uma mola hidatiforme completa coexistindo com feto normal. A análise genética mostrou feto diploide com genoma biparental e tecido molar com diploidia paterna. Este caso ressaltou que as gestações com mola hidatiforme completa poderão ainda ocorrer, mesmo que a gravidez seja realizada após uma injeção intracitoplasmática de espermatozoides. Foram realizadas uma revisão dos raros casos descritos na literatura e uma explicação da patogenia desta condição rara.

Correspondence

Tiago Matos Ferraz

Servico de Ginecologia e Obstetrícia, Centro Hospitalar de São Joũo Alameda Professor Hernôni Monteiro, 4200319

CEP: 4202-45]

Porto, Portugal

Received

10/02/2012

Accepted with modifications

$17 / 09 / 2012$
'Serviço de Ginecologia e Obstetrícia, Centro Hospitalar de São João do Porto - Porto, Portugal. ${ }^{2}$ Serviço de Anatomia Patológica, Centro Hospitalar de São João do Porto - Porto, Portugal. ${ }^{3}$ Departamento de Genética da Faculdade de Medicina, Universidade do Porto - Porto, Portugal. Conflict of interest: none. 


\section{Introduction}

Estimates from studies conducted in North America, Australia, New Zealand, and Europe have shown that the incidence of hydatidiform mole ranges from 0.57 to 1.1 per 1000 pregnancies, whereas others in Southeast Asia and Japan have described an incidence as high as 2.0 per 1,000 pregnancies ${ }^{1}$.

Hydatidiform mole coexisting with live fetuses is a rare event with a reported incidence of 1 in 20,000 to 100,000 pregnancies ${ }^{2,3}$. In many instances, these pregnancies are associated with significant maternal and fetal complications including preeclampsia, thromboembolic disease, hyperemesis, hemorrhage, and intrauterine demise. Partial hydatidiform mole or twin pregnancy, with complete hydatidiform mole coexisting with a normal fetus (CHMCF), falls into this category. The fetus of a triploid partial mole tends to die in the first trimester, while a complete mole coexisting with a normal twin fetus allows for expectant management ${ }^{2,4,5}$.

With the introduction of assisted reproductive techniques (ART), a significant rise in the incidence of multiple pregnancies has been reported, which is associated with increased maternal and perinatal complications. Complete hydatidiform mole is possibly associated with advanced maternal age and use of ART, and this reflects how difficult the decision of termination is for such couples. A few cases of CHMCF after intracytoplasmic sperm injection (ICSI) have been reported, mostly in the Asian population ${ }^{6-15}$.

This case reported an achieved pregnancy after ICSI of a $\mathrm{CHMCF}$ with comprehensive genetic analysis.

\section{Case Report}

The patient was a 39-year-old Caucasian woman, gravida 2, para 0 with one previous spontaneous abortion.

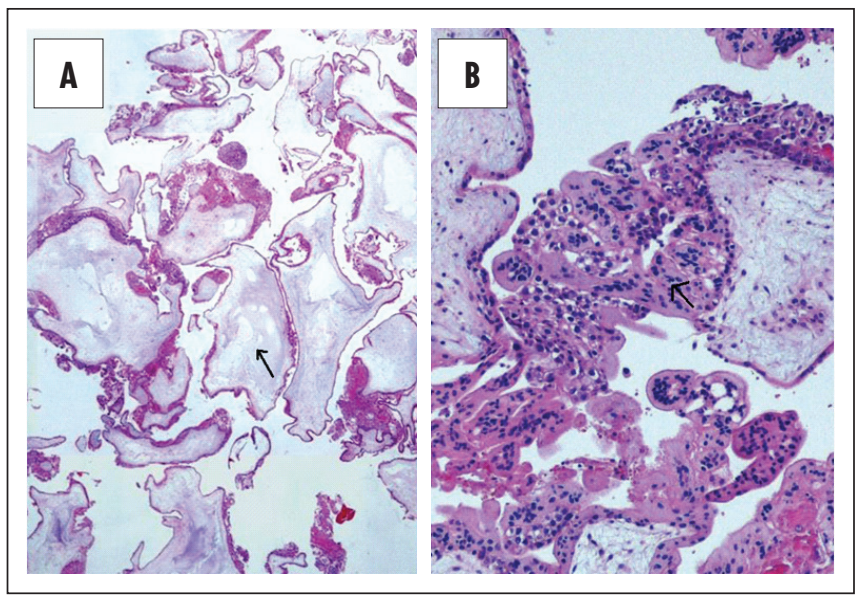

Figure 1. Complete hydatidiform mole. (A) Histological low power view showing numerous edematous villi with frequent cistern formation (arrow); (B) histological high power view showing hyperplastic trophoblast (arrow).
She had a history of secondary infertility three years preceding this pregnancy and had sought medical advice. Male factor infertility based on oligoastenospermy was diagnosed by a single semen analysis, and the couple was informed. ICSI cycle treatment was started and pregnancy was achieved after two embryos were transferred.

Routine ultrasound examination at the $12^{\text {th }}$ gestational week showed multiple cystic placenta, that resembled hydatidiform mole and a normal developing fetus, suggesting a twin pregnancy.

After referral to our department, a more precise diagnosis was attempted by offering genetic analysis of chorionic villous sampling from the hydroptic parenchyma and amniocentesis, which was refused by the couple, who decided to terminate the pregnancy. This was performed with vaginal misoprostol followed by aspiration curettage. The pre-evacuation serum $\beta$-hCG level was $1,402,565 \mathrm{mUI} / \mathrm{mL}$, and the TSH one was $0.006 \mathrm{ng} / \mathrm{mL}$. Based on these results, propylthiouracil as well as hydrocortisone were started in order to prevent thyrotoxic storm. The patient was discharged two days later, asymptomatic.

Pathological examination presented a product of conception that macroscopically comprised: abundant fragments of placental tissue with marked cystic swelling of the villi; fragments of grossly normal placenta, and an intact normal female fetus with biometric and growth parameters that were consistent of 14 weeks of gestational age. Microscopic examination (Figure 1) confirmed these macroscopic aspects showing frequent cistern formation and areas of hyperplastic trophoblast, which are typical of a complete hydatidiform mole (Figure 1). The other placental fragments corresponded to normal placental parenchyma (Figure 2). These morphological features allowed diagnosing a twin pregnancy consisting of a

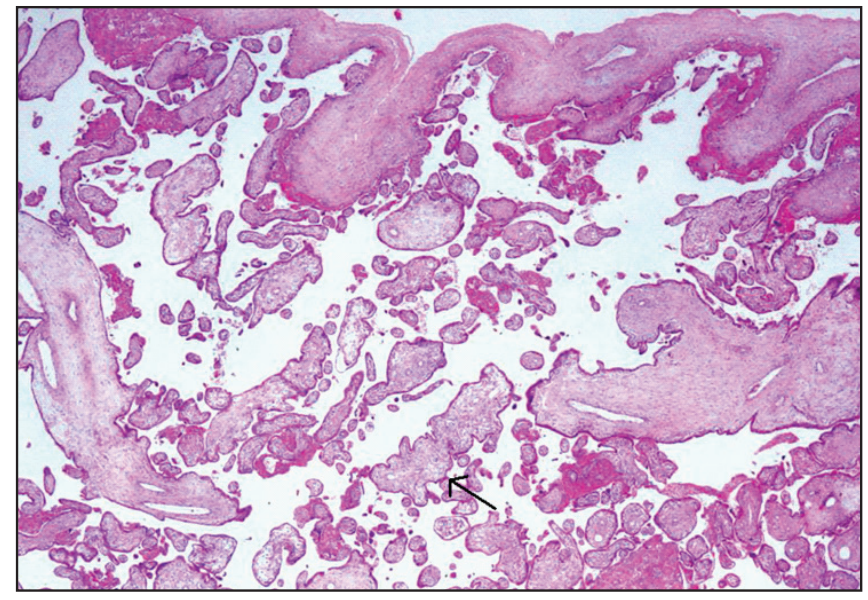

Figure 2. Normal placenta. Histology shows normal placental parenchyma composed of immature intermediate and mesenchymal villi (arrow) adequate to 14 weeks of gestational age. 
complete hydatidiform mole and a normal 14-gestationalweek-old placenta and fetus.

Genetic analysis, using polymorphic markers (D13S258; D13S631; D18S51; D18S535; D21S1414; and D21S1437), confirmed normal diploid fetus $(46, \mathrm{XX})$ with biparental genome and a molar tissue with paternal diploidy.

The initial serum $\beta$-hCG declined appropriately during eight weeks reaching $28.74 \mathrm{mUI} / \mathrm{mL}$ and then a plateau. Hysteroscopy was performed, and the diagnosis of persistent gestational trophoblastic disease was found. There were no evidences of persistent or metastatic disease during the three-year follow-up.

\section{Discussion}

This case presents the difficultness of a differential diagnosis, in which a detailed morphological ultrasound of the fetus is a decisive procedure. Few cases of CHMCF have been reported over the last two decades. These pregnancies are often associated with severe maternal complications, such as persistent vaginal bleeding, thromboembolic disease, severe preeclampsia, and persistent gestational trophoblastic neoplasia (GTN $)^{2,5,16}$. Moreover, this case represents one of the rarest ones occurring after reproductive medicine techniques, namely ICSI.

The challenge was to differentiate a singleton pregnancy consisting of a partial mole and a live triploid fetus and a twin pregnancy with one placenta exhibiting a complete mole and the other sustaining a normal fetus ${ }^{4}$. Unlike partial hydatidiform mole that is commonly associated with multiple fetal anomalies and is managed by immediate termination of pregnancy, reported cases of twin pregnancy with complete hydatidiform mole (the present case) are not associated with fetal anomalies in the coexisting fetus. Although rare, twin pregnancies comprising a mole and a healthy fetus are a complex clinical condition. The correct diagnosis is extremely important based on the high frequency of spontaneous abortion and intrauterine death and also for severe maternal complications, mainly preeclampsia, which frequently prompt pregnancy termination. Accordingly, prenatal diagnosis should always be based on fetal karyotype using chorionic villous sampling, amniocentesis, or fetal blood sample $e^{2,4}$.

Many series and several case reports have been published regarding a complete mole and a coexisting normal twin fetus (CHMCF) $)^{2-10,13-15,17,18}$. Twin pregnancies including a mole and a healthy fetus give rise to complex clinical considerations, especially in a strongly desired pregnancy. Sebire et al. ${ }^{2}$ reported the largest series so far comprising $77 \mathrm{CHMCF}$, with approximately $27 \%$ of the pregnancies achieving live birth and $19 \%$ developed persistent gestational trophoblastic disease (pGTD), without significant differences between those who chose to electively terminate pregnancy and those who did not. Recently, Massardier et al..$^{5}$ published a series of 14 cases with similar live birth percentage and a $50 \%$ pGTD. Single case reports were also published ${ }^{13-15}$, which prompts for understanding in medical community the importance of this diagnosis.

Pregnancies complicated by CHMCF may result in a viable live-born infant in approximately $40 \%$ of the time. Continuation of such pregnancy may be an option, granted the mother has been appropriately counseled on the numerous risks.

The potential risk for pGTD (from 19.0 to $62.5 \%)^{3}$ is the most problematic factor when counseling these couples. Based on small series and case reports, most of these pregnancies were electively terminated in light of this potential risk. A study, undertaken by Niemann et al. ${ }^{3}$, in which 270 histological and cytogenetically confirmed complete hydatidiform moles were analyzed to evaluate the risk of pGTD and other obstetrics complications, showed no differences between singleton and twin molar pregnancies. Expectant management in these cases may be permitted ${ }^{13}$, and the risk does not change with advanced gestational age ${ }^{3}$.

In partial hydatidiform moles, there are fetal or embryonic tissue and chorionic villi with focal edema. Most partial moles have a triploid karyotype (usually 69, $\mathrm{XXY}$ ), resulting from the fertilization of an apparently normal ovum by two sperms. Complete moles (CM) are usually diploid androgenic conceptus due to loss of the maternal nuclear genome with either fertilization by a single haploid sperm cell that duplicates to produce a 46, XX (monospermic) CM or by two sperms resulting in a $46, \mathrm{XX}$ or $46, \mathrm{XY}$ (dispermic) $\mathrm{CM}^{19}$. This results in excessive trophoblastic growth. No embryo development is observed due to lack of genes transcribed from maternally derived genes.

To our best knowledge, only 17 CHMCF were reported $^{9-12,15,19-22}$ as a result of ART since 1977, when a morphological classification of molar pregnancies was established, with seven of them resulting from the ICSI technique $^{6-12}$ (Table 1).

These events could still occur, although the possibility of dispermic fertilization and digyny should be reduced or absent in cycles where ICSI has been employed. During the ICSI process, it is assumed that in the pronuclear stage a haploid set of male and female chromosomes should be obtained. Male and female pronuclei are usually formed simultaneously containing sperm and oocyte chromatin. These structures, although small and faint, may be visualized as early as $16-18 \mathrm{H}$ after ICSI. Pronuclei come into close contact, eventually lose their apposed pronuclear membranes, and enter into syngamy. Unfortunately, the identification of pronuclei neither ensures a normal 
Table 1. Literature reported cases of complete hydatidiform mole coexisting with normal fetus after intracytoplasmic sperm injection

\begin{tabular}{|c|c|c|c|c|c|}
\hline Authors & Maternal age & GA at delivery/abortion (weeks) & Complications & Live neonate & PTD \\
\hline Petignat ef al. ${ }^{10}$ & 29 & 15 & Preeclampsia & No & (?) \\
\hline Hamanove et al. ${ }^{6}$ & 40 & 33 & Preterm labor, FGR & Yes & No \\
\hline Dedes et al. ${ }^{8}$ & 32 & 26 & Preterm labor & No & (?) \\
\hline Yamada ef al. ${ }^{7}$ & 33 & 15 & Preeclampsia & No & Yes \\
\hline Dolapcioglu ef al. ${ }^{9}$ & 34 & 29 & gHTA/maternal bleeding & Yes & No \\
\hline Vandenhove et al."1 & 31 & 18 & Maternal bleeding & No & Yes \\
\hline Ferraz ef al.* & 39 & 13 & None & No & Yes \\
\hline
\end{tabular}

GA: gestational age; PTD: persistent trophoblastic disease; FGR: fetal growth restriction; gHTA: gestational hypertension; * present case.

fertilization process nor guarantees paternal and maternal origins for each pronucleus.

Recently, using polymorphic DNA markers, Niemann et al. investigated the origin of twin pregnancies that comprised androgenetic diploid mole and a normal fetus. Accordingly, duplication of the paternal chromosomes before pronuclear fusion and development of a triploid pronuclear stage with one haploid maternal pronucleus and two haploid paternal pronuclei was described ${ }^{23}$. However, this model cannot be explained according to the normal process for early steps of fertilization. Another author described endoreduplication in the maternal pronucleus as a possible cause of digynic triploidy, stating that there was evidence only for maternal contribution for abnormal oocytes ${ }^{24}$.

Post-zygotic events may also be a possibility, giving rise to speculations regarding the earliest stages of fertilization and more specifically a complete mole and a normal pregnancy dichorionic pregnancy after $\mathrm{ICSI}^{24}$.

The ability to diagnose a molar placenta in an ongoing pregnancy is clinically challenging. This case demonstrated two main features: first, ultrasound alone may not be sufficient for an accurate management although it is a good diagnostic tool in molar pregnancies; secondly, complete molar pregnancies may still occur, despite the pregnancy being achieved by ICSI.

\section{References}

1. Bracken MB. Incidence and aetiology of hydatidiform mole: an epidemiological review. Br J Obstet Gynaecol. 1987;94(12): $1123-35$.

2. Sebire NJ, Foskett M, Paradinas FJ, Fisher RA, Francis RJ, Short $D$, et al. Outcome of twin pregnancies with complete hydatidiform mole and healthy co-twin. Lancet. 2002;359(9324):2165-6.

3. Niemann I, Sunde L, Petersen LK. Evaluation of the risk of persistent trophoblastic disease after twin pregnancy with diploid hydatidiform mole and coexisting normal fetus. Am J Obstet Gynecol. 2007;197(1):45.e1-5.

4. Vaisbuch E, Ben-Arie A, Dgani R, Perlman S, Sokolovsky N, Hagay Z. Twin pregnancy consisting of a complete hydatidiform mole and co-existent fetus: report of two cases and review of literature. Gynecol Oncol. 2005;98(1):19-23.

5. Massardier J, Golfier F, Journet D, Frappart L, Zalaquett M, Schott $A M$, et al. Twin pregnancy with complete hydatidiform mole and coexistent fetus: obstetrical and oncological outcomes in a series of 14 cases. Eur J Obstet Gynecol Reprod Biol. 2009; 143(2):84-7.

6. Hamanoue H, Umezu N, Okuda M, Harada N, Ohata T, Sakai H, et al. Complete hydatidiform mole and normal live birth following intracytoplasmic sperm injection. J Hum Genet. 2006;5 1 (5):477-9.

7. Yamada T, Matsuda T, Kudo M, Yamada T, Moriwaki M, Nishi S, et al. Complete hydatidiform mole with coexisting dichorionic diamniotic twins following testicular sperm extraction and intracytoplasmic sperm injection. J Obstet Gynaecol Res. 2008;34(1):121-4.

8. Dedes I, Christodoulou E, Ziogas V. Complete hydatidiform mole coexisting with a viable pregnancy as twins after intracytoplasmic sperm injection: a case report. J Reprod Med. 2008;53(3):227-30.

9. Dolapcioglu K, Gungoren A, Hakverdi S, Hakverdi AU, Egilmez E. Twin pregnancy with a complete hydatidiform mole and coexistent live fetus: two case reports and review of the literature. Arch Gynecol Obstet. 2009;279(3):431-6.

10. Petignat P, Senn A, Hohlfeld P, Blant SA, Laurini R, Germond M. Molar pregnancy with a coexistent fetus after intracytoplasmic sperm injection. A case report. J Reprod Med. 2001;46(3):270-4.

11. Vandenhove $M$, Amant F, van Schoubroeck D, Cannie $M$, Dymarkowski S, Hanssens M. Complete hydatidiform mole with co-existing healthy fetus: a case report. J Matern Fetal Neonatal Med. 2008;21(5):341-4.

12. Kashani EBP, Roshandel G, Roshandel D. Molar pregnancy and co-existent foetus: a report of two cases. J Clin Diagn Res. 2009;3(1):1334-7.

13. Shazly SA, Ali MK, Abdel Badee AY, Alsokkary AB, Khodary MM, Mostafa NA. Twin pregnancy with complete hydatidiform mole and coexisting fetus following ovulation induction with a 
non-prescribed clomiphene citrate regimen: a case report. J Med Case Rep. 2012;6:95.

14. Singh $M$, Shaltoot $N$, Emovon E. Twin pregnancy with complete hydatidiform mole and co-existent viable fetus. J Obstet Gynaecol. $2011 ; 31(8): 767-8$.

15. Chesnais AL, Le Breton F, Devouassoux-Shisheboran M, Huissoud C, Massardier J, Quilichini B, et al. Twin pregnancy with both complete hydatiform mole and coexistent alive fetus: report of a non-antenatal diagnosed case. Ann Pathol. 2011 ; 31 (4):299-302.

16. Sánchez-Ferrer ML, Machado-Linde F, Martínez-Espejo Cerezo A, Peñalver Parres C, Ferri B, López-Expósito I, et al. Management of a Dichorionic twin pregnancy with a normal fetus and an androgenetic diploid complete hydatidiform mole. Fetal Diagn Ther. 2012 [Epub ahead of print].

17. Aguilera M, Rauk P, Ghebre R, Ramin K. Complete hydatidiform mole presenting as a placenta accreta in a twin pregnancy with a coexisting normal fetus: case report. Case Rep Obstet Gynecol. 2012;2012:405085.

18. Sasaki Y, Ogawa K, Takahashi J, Okai T. Complete hydatidiform mole coexisting with a normal fetus delivered at 33 weeks of gestation and involving maternal lung metastasis: a case report. J Reprod Med. 2012;57(7-8):301-4.
19. Fluker MR, Yuzpe AA. Partial hydatidiform mole following transfer of a cryopreserved-thawed blastocyst. Fertil Steril. $2000 ; 74(4): 828-9$.

20. Guzman González E, Gaviño Gaviño F, Valero Origel A, Deschamps Díaz H, Ramírez Fernández MA, Miranda Lamadrid $M$. Twin pregnancy with complete mole and coexisting fetus after in vitro fertilization and embryo transfer complicated with placenta previa accreta. A case report. Ginecol Obstet Mex. $2009 ; 77(3): 151-5$.

21. Montes-de-Oca-Valero F, Macara L, Shaker A. Twin pregnancy with a complete hydatidiform mole and co-existing fetus following in-vitro fertilization: case report. Hum Reprod. 1999;14(1 1):2905-7.

22. Hsu CC, Lee IW, Su MT, Lin YC, Hsieh C, Chen PY, et al. Triple genetic identities for the complete hydatidiform mole, placenta and co-existing fetus after transfer of a single in vitro fertilized oocyte: case report and possible mechanisms. Hum Reprod. 2008;23(12):2686-91.

23. Niemann I, Bolund L, Sunde L. Twin pregnancies with diploid hydatidiform mole and co-existing normal fetus may originate from one oocyte. Hum Reprod. 2008;23(9):2031-5.

24. Rosenbusch BE. Mechanisms giving rise to triploid zygotes during assisted reproduction. Fertil Steril. 2008;90(1):49-55. 